\title{
Perlindungan Konsumen dalam Jual Beli Emas Melalui Platform Digital "Tamasia"
}

\author{
Kadek Ratih Indriyani Putri ${ }^{1}$ \\ ${ }^{1}$ Program Studi Magister (S2) Kenotariatan Fakultas Hukum Universitas Udayana, \\ E-mail: kdratihindriyani@yahoo.com
}

\begin{tabular}{l}
\hline Info Artikel \\
\hline Masuk : 14 Agustus 2019 \\
Diterima : 03 September 2019 \\
Terbit : 30 Desember 2019 \\
Keywords : \\
Legal protection; Buy and sell \\
gold; Digital platform \\
\\
Kata kunci: \\
Perlindungan hukum; Jual beli \\
emas; Platform digital \\
Corresponding Author: \\
Penulis Pertama, E-mail: \\
kdratihindriyani@yahoo.com \\
DOI : \\
10.24843/AC.2019.v04.i03.p11
\end{tabular}

\begin{abstract}
Tamasia is one of the digital platforms where consumers can buy and sell gold at any time. Tamasia is based on a technology company called PT Tamasia Global Sharia which has been registered in Kemkominfo on 23 November 2017 with registration number 00480/DJAI. PSE/11/2017, and supervised by BAPPEBTI. Normative legal research is used in the writing of this journal using a statutory approach and a conceptual approach. The findings of the study were consumers who felt harmed by Tamasia could report to the PPNS ITE Directorate of Information Security, and the form of supervision provided by $B A P P E B T I$ is a preventive oversight and repressive supervision.

Abstrak
Tamasia adalah salah satu platform digital dimana para
nasabahnya dapat melakukan jual beli emas dimana dan kapan
saja. Tamasia ini bernaung pada perusahaan teknologi bernama
PT Tamasia Global Sharia yang telah terdaftar di Kemkominfo
pada tanggal 23 November 2017 dengan Nomor Tanda Daftar
00480/DJAI.PSE/11/2017, dan diawasi oleh Bappebti. Penelitian
hukum normatif dipilih untuk penulisan jurnal ini, juga memilih
pendekatan perundang-undangan dan pendekatan konseptual
untuk diterapkan dalam penulisan jurnal. Perolehan temuan
penelitian ini ialah nasabah yang merasa dirugikan oleh Tamasia
dapat melaporkan ke PPNS ITE Direktorat Keamanan Informasi,
dan bentuk pengawasan yang diberikan oleh Bappebti ialah
berupa pengawasan preventif dan pengawasan represif.
\end{abstract}

\section{Pendahuluan}

Kegiatan jual beli sering dipraktekkan oleh manusia dan sudah menjadi suatu kebiasaan dalam kehidupan masyarakat dimana kegiatan tersebut dilakukan atas dasar kesepakatan bersama. Kegiatan jual beli ini telah ada semenjak lahirnya manusia, dimana manusia adalah makhluk sosial yang berarti saling memerlukan bantuan orang lain juga tidak dapat hidup sendiri. Seiringnya perubahan dan perkembangan jaman, budaya, dan teknologi, kegiatan jual beli yang dulu dilakukan dengan cara pertukaran barang yang disebut juga dengan barter, yang kemudian alat transaksi pembayaran yang digunakan pada saat ini adalah berupa uang, baik dalam bentuk uang logam ataupun uang kertas. Kegiatan jual beli ini dapat terjadi apabila salah seorang manusia memiliki barang atau jasa yang dibutuhkan oleh manusia lainnya, sehingga manusia yang membutuhkan barang atau jasa tersebut harus membeli dan membayar atas apa yang dibutuhkan. Barang-barang yang dapat 
diperjualbelikan pun tidak hanya berupa barang sekunder, primer, maupun tersier saja, melainkan kini jual beli emas makin marak di kalangan masyarakat terutama dalam hal kegiatan berinvestasi.

Investasi emas banyak diminati di kalangan masyarakat karena ini tergolong cukup mudah dilakukan. Investasi emas baik dalam bentuk koin, batangan, atau emas yang telah menjadi perhiasan ini memiliki kelebihan dimana nilai dari emas itu sendiri dari tahun ketahun cenderung stabil, bahkan mengalami kenaikan harga emas apabila laju inflasi semakin tinggi. Joko Salim menerbitkan satu buku yang mengemukakan bahwa harga emas dipercaya hendak selalu mengalami kenaikan mengikuti tingkat kenaikan inflasi dalam suatu waktu tertentu. ${ }^{1}$ Dengan membeli emas baik dalam wujud koin, emas batang, atau perhiasan kemudian di simpan dalam kurun waktu tertentu, kemudian pada waktu terjadi kenaikan harga emas baik secara signifikan atau tidak, emas yang sudah dibeli dapat dijual dengan nilai yang lebih tinggi dari harga beli emas sebelumnya sehingga memperoleh keuntungan dari kenaikan harga emas tersebut.

Seiring perkembangan dan semakin modernnya teknologi kini, berinvestasi emas kini dapat dilakukan dengan mudah melalui suatu aplikasi. Kemajuan dan kecanggihan teknologi dari waktu ke waktu sangat terasa mempermudah segala aktifitas yang dilakukan manusia sehingga lebih efisien, tidak dipungkiri kemajuan dan kecanggihan teknologi pun memiliki pengaruh positif dan negatif bagi kehidupan masyarakat. Adanya jaringan internet kini telah memberikan berbagai kemudahan pelayanan, apalagi internet merupakan salah satu sumber dari media komunikasi sehingga kita dapat berinteraksi dengan orang yang keberadaannya jauh sekalipun. Adanya dukungan jaringan internet dan juga pengaruh dari era globalisasi membawa dampak terhadap perekonomian dunia kedalam babak baru yang memiliki istilah digital economy atau ekonomi digital. ${ }^{2}$ Indonesia sudah lama mengenal transaksi atau bisnis melalui media elektronik yang biasa diketahui dengan sebutan electronic commerce atau e-commerce, sebelumnya juga Indonesia sudah mengenal terlebih dahulu istilah credit cards, automated teller machines, dan telephone banking. ${ }^{3}$

Salah satu perusahaan teknologi yakni PT Tamasia Global Sharia menciptakan platform digital dimana nasabah dapat membeli dan memiliki emas kapanpun dan dimanapun, dengan cara mengunduh aplikasi Tamasia pada telepon seluler nasabah. Beragam fitur disediakan pada platform digital ini yaitu berupa Jual Beli Emas, Transfer Emas, Cetak Emas, dan Impianku. Tamasia juga memiliki keunggulan dimana para nasabah dapat membeli emas mulai dari Rp10.000 (sepuluh ribu rupiah) dan transaksi dapat dilakukan kapanpun dan dimanapun. Selain itu para nasabah akan mendapatkan informasi berupa grafik harga jual beli emas setiap harinya, didukung seratus persen emas fisik dan tersimpan di Antam, juga cetakan emas logam mulia antam yang telah dimiliki dapat dijual kembali dengan harga pasar. Tidak hanya itu saja, Tamasia juga telah terdaftar di Kementerian Komunikasi dan Informatika (selanjutnya disebut Kemkominfo) dan diawasi oleh Badan Pengawas

${ }^{1}$ Salim, Joko. (2010). Jangan Investasi Emas sebelum Baca Buku Ini !. Jakarta: Transmedia Pustaka, hal. 160

2 Khotimah, Cindy Aulia. (2015). Perlindungan Hukum bagi Konsumen dalam Transaksi Jual Beli-Online (E-Commerce)". Bussiness Law Review, 1(14)

${ }^{3}$ Sumasyhari, Didin. (2016). Perlindungan Konsumen E-Commerce pada Lazada.co.id Tinjauan Hukum Ekonomi Islam dan Hukum Positif, Institut Agama Islam Negeri (IAIN) Surakarta 
Perdagangan Berjangka Komoditi (selanjutnya disebut BAPPEBTI). ${ }^{4}$ Namun Tamasia sendiri tidak mempunyai ijin dari Otoritas Jasa Keuangan (selanjutnya disebut OJK) karena Tamasia merupakan perusahan jual beli emas melalui aplikasi digital, bukan perusahaan yang menghimpun dan memutar dana penggunanya. Itu sebabnya Tamasia tidak berada dibawah naungan OJK.

Pasal 1 Ayat (1) Undang-Undang Nomor 8 Tahun 1999 tentang Perlindungan Konsumen, menentukan pengertian dari perlindungan konsumen adalah segala upaya yang menjamin adanya kepastian hukum untuk memberi perlindungan kepada konsumen. Dalam bertransaksi konsumen berhak untuk mendapatkan rasa nyaman, aman, dan keselamatan dalam mengunakan barang atau jasa; memilih serta mendapatkan barang atau jasa sesuai dengan nilai tukar, kondisi, atau jaminan yang telah disepakati; berhak untuk diberikan informasi yang jelas, benar, dan jujur atas barang atau jasa; berhak untuk didengarkan pendapatnya atas keluhan mengenai barang atau jasa yang digunakan; dan berhak mendapatkan advokasi, perlindungan, dan upaya penyelesaian sengketa perlindungan konsumen yang patut. Untuk mendapatkan semua hak tersebut, maka konsumen juga memiliki kewajiban yang harus dilakukan dalam bertransaksi diantaranya demi rasa aman dan keselamatan, maka konsumen wajib membaca dengan teliti petunjuk atau prosedur informasi pemakaian atas barang atau jasa; memiliki itikad baik dalam melakukan transaksi pembelian barang atau jasa; melakukan pembayaran sesuai dengan nilai tukar yang disepakati; serta mengikuti upaya penyelesaian sengketa perlindungan konsumen secara patut. ${ }^{5}$

Pada transaksi e-commerce timbul permasalahan mengenai kepastian hukumnya, seperti jaminan keaslian data, kerahasiaan dokumen, atau perlindungan yang didapatkan konsumen apabila terjadinya pelanggaran terhadap kesepakatan atau kontrak yang telah disepakati secara digital. Oleh karena itu jaminan keamanan terhadap konsumen sangat diperlukan agar menambah keyakinan konsumen guna melakukan transaksi digital. Ruang lingkup privat transaksi e-commerce ini meliputi pelaku usaha, pelaku usaha dan konsumen, pribadi, instansi, dan antara instasi dengan pelaku usaha sesuai dengan peraturan perundang-undangan. ${ }^{6}$ Selanjutnya mengenai bisnis e-commerce ini dimuat pada Pasal $1457 \mathrm{KUH}$ Perdata dan UndangUndang Nomor 11 Tahun 2008 tentang Internet dan Transaksi Elektronik (selanjutnya disebut UU ITE). Perdagangan yang dilakukan secara elektronik ini juga dimuat dalam Pasal 65 dan Pasal 66 Undang-Undang Nomor 7 Tahun 2014 tentang Perdagangan.

Di Indonesia menurut ketentuan hukum yang berlaku, gugatan perdata dilakukan apabila terjadinya wanprestasi atau perbuatan yang melanggar hukum. Kedua hal tersebut ada dalam ketentuan Buku III KUH Perdata Pasal 1243 dan Pasal 1365. Bilamana konsumen mendapatkan kerugian yang dikarenakan telah melakukan transaksi jual beli secara online maka gugatan yang dialami adalah gugatan wanprestasi karena merujuk pada pelaku usaha yang melanggar kewajibannya dalam

4 PT Global Tamasia Sharia. (2019). Tentang Tamasia. Available from https://www.tamasia.co.id/ (Diakses 22 Juni 2019)

5 Brahmanta, A. G. A., \& Sarjana, I. M. (2016). Perlindungan Hukum Bagi Konsumen dalam Perjanjian Baku Jual Beli Perumahan dengan Pihak Pengembang di Bali. Acta Comitas: Jurnal Hukum Kenotariatan, (2), 208-219

6 Alkaff, F. (2018). Keabsahan Transaksi Jual Beli Online (Studi Perbandingan KUH Perdata dan Kompilasi Hukum Ekonomi Syariah), Doctoral dissertation, Universitas Mataram 
kontrak elektronik yang telah disepakati sehingga menimbulkan kerugian yang dialami konsumen. ${ }^{7}$

Konsumen yang akan melakukan jual beli emas melalui Tamasia sebelumnya telah dijelaskan harus mengunduh aplikasi tersebut kemudian melakukan registrasi dengan mendaftarkan nomor telepon seluler serta memasukkan nomor pin yang akan digunakan sebagai kata sandi Tamasia. Setelah akun Tamasia telah aktif, nasabah perlu memverifikasi data akun dengan cara memasukkan nomor telepon seluler, email, dan Kartu Tanda Penduduk (disebut dengan KTP) nasabah. Berhubung Tamasia adalah aplikasi platform digital dimana segala sesuatunya dilakukan secara online, maka nasabah perlu memberikan nomor KTP pada kolom yang disediakan, kemudian menyertakan foto KTP dan foto diri dengan KTP. Dengan nasabah telah memberikan informasi kependudukannya melalui online, maka juga sangat diperlukan perlindungan hukum agar data yang telah diberikan aman, sehingga dapat menjaga privasi nasabah. Karenanya, berdasarkan permasalahan yang timbul dalam transaksi e-commerce khususnya dalam pelaksanaan investasi emas dengan menggunakan aplikasi platform digital Tamasia, disusunlah penulisan jurnal ini menggunakan judul Perlindungan Konsumen Dalam Jual Beli Emas Melalui Platform Digital "Tamasia".

\section{Metode Penelitian}

Pada tulisan ini mengaplikasikan penelitian hukum normatif yang berdasarkan kepustakaan yang mengkaji studi dokumen yang terdiri dari bahan data sekunder atau peraturan perundang-undangan. Kemudian pendekatan pada tulisan ini yakni pendekatan perundang-undangan (statute approach) dan pendekatan konseptual (conceptual approach). Selanjutnya menggunakan bahan hukum primer dan bahan hukum sekunder, serta bahan hukum tersier, yang dalam pengumpulan bahan hukum tersebut menggunakan teknik studi dokumen dan analisis yang dipilih adalah teknik deskriptif.

\section{Hasil dan Pembahasan}

\subsection{Peran Kemkominfo dan Bappebti dalam memberikan Perlindungan Hukum terhadap Nasabah Tamasia}

\subsubsection{Peran Kementerian Komunikasi dan Informatika (Kemkominfo)}

Seperti yang sudah dijabarkan pada bab pendahuluan, bahwa aplikasi platform digital Tamasia tidak mempunyai ijin dari OJK namun telah terdaftar di Kemkominfo. Tamasia dapat ditemukan di laman resmi Penyelenggara Sistem Elektronik (PSE) Kominfo. Tamasia terdaftar pada tanggal 23 November 2017 dengan Nomor Tanda Daftar 00480/DJAI.PSE/11/2017. Tamasia sendiri masuk dalam kategori perdagangan, yang mana nama perusahaannya adalah Tamasia Global Sharia. ${ }^{8}$ Kemkominfo berdiri sesuai dengan Keputusan Presiden Nomor 10 Tahun 2005 tentang Unit Organisasi dan

7 Akhmaddhian, S., \& Agustiwi, A. (2018). Perlindungan Hukum Terhadap Konsumen Dalam Transaksi Jual Beli Secara Elektronik Di Indonesia. UNIFIKASI: Jurnal Ilmu Hukum, 3(2), 40-60.

8 Direktorat Tata Kelola Aplikasi Informatika. (2019). Penyelenggara Sistem Elektronik Terdaftar. Available from https://pse.kominfo.go.id/pse-terdaftar (Diakses 12 Juli 2019) 
Tugas Eselon I Kementerian Negara Republik Indonesia, berubah menjadi Peraturan Presiden (selanjutnya disebut Perpres) Nomor 15 Tahun 2005. Selanjutnya sebagai implementasi ketentuan Pasal 11 Undang-Undang Nomor 39 Tahun 2008 tentang Kementerian Negara telah dikeluarkan Perpres Republik Indonesia Nomor 54 Tahun 2015 tanggal 4 Mei 2005 tentang Kementerian Komunikasi dan Informatika. ${ }^{9}$

Direktorat Jenderal Aplikasi Informatika (selanjutnya disebut Ditjen Aptika) memiliki kewajiban dalam mengatur perumusan dan penerapan aturan di bidang Penata Kelolaan Aplikasi Informatika. Tugas tersebut ditetapkan sesuai dengan Perpres Republik Indonesia Nomor 54 Tahun 2015 tanggal 4 Mei 2005 tentang Kementerian Komunikasi dan Informatika. Perpres tersebut kemudian dijabarkan kedalam Peraturan Menteri Komunikasi dan Informatika Nomor 1 Tahun 2016 tentang Organisasi dan Tata Kerja Kementerian Komunikasi dan Informatika yang mengatur kedudukan, tugas pokok, dan fungsi serta susunan organisasi Ditjen Aptika. ${ }^{10}$

Ditjen Aptika dalam kedudukannya memiliki kewajiban dan tanggung jawab terhadap Menteri. Ditjen Aptika memiliki tugas pokok untuk membuat serta menerapkan peraturan dan standardisasi teknis di bidang aplikasi informatika yang dipimpin oleh seorang Direktur Jenderal. Ditjen Aptika sendiri memiliki beberapa fungsi antara lain perumusan peraturan pada bidang aplikasi informatika; penerapan peraturan di bidang aplikasi informatika; membuat norma, standar, prosedur, dan kriteria di bidang aplikasi informatika; memberikan arahan, pengajaran, dan evaluasi di bidang aplikasi informatika; serta pelaksanaan administrasi Ditjen Aptika. Untuk menjalankan semua fungsi tersebut maka dibentuklah struktur organisasi dalam Ditjen Aptika diantaranya:

a. Sekretariat Direktorat Jenderal Aplikasi Informatika (Setditjen Aptika), mempunyai tugas melaksanakan pelayanan teknis dan administrasi kepada seluruh satuan organisasi di lingkungan Ditjen Aptika;

b. Direktorat E-Government (Dit.e-Gov), mempunyai tugas melaksanakan perumusan kebijakan, pelaksanaan kebijakan, penyusunan norma, standar, prosedur, kriteria, dan pemberian bimbingan teknis, dan evaluasi di bidang eGovernment;

c. Direktorat E-Business (Dit.e-Business), mempunyai tugas melaksanakan perumusan kebijakan, pelaksanaan kebijakan, penyusunan norma, standar, prosedur, kriteria dan pemberian bimbingan teknis, dan evaluasi di bidang eBusiness;

d. Direktorat Pemberdayaan Informatika (Dit. PI), mempunyai tugas melaksanakan penyiapan perumusan kebijakan, pelaksanaan kebijakan, penyusunan norma, standar, prosedur, kriteria serta pemberian bimbingan teknis, dan evaluasi di bidang pemberdayaan informatika;

e. Direktorat Pemberdayaan Industri Informatika (Dit. PII), mempunyai tugas melaksanakan perumusan kebijakan, pelaksanaan kebijakan, penyusunan

\footnotetext{
9 Sekretariat Ditjen Aplikasi Informatika, Kementerian Komunikasi dan Informatika. (2017). Laporan Tahunan Direktorat Jenderal Aplikasi Informatika "Peningkatan Ekonomi Kerakyatan Melalui Pemanfaatan TIK". Jakarta, hal. 2

${ }^{10} \mathrm{Ibid}$, hal. 4
} 
norma, standar, prosedur, kriteria serta pemberian bimbingan teknis, dan evaluasi di bidang pemberdayaan industri informatika;

f. Direktorat Keamanan Informasi (Dit. Kaminfo), mempunyai tugas melaksanakan perumusan kebijakan, pelaksanaan kebijakan, penyusunan norma, standar, prosedur, kriteria serta pemberian bimbingan teknis, dan evaluasi di bidang keamanan informasi. ${ }^{11}$

Terdaftarnya aplikasi platform digital Tamasia ini di PSE Terdaftar Kominfo, pemerintah sudah memberikan suatu bentuk perlindungan hukum kepada konsumen atau nasabah Tamasia sendiri. Bila mengalami suatu penipuan atau tindakan yang membuat ketidaknyamanan untuk para nasabah yang dilakukan oleh aplikasi platform digital Tamasia ini, nasabah dapat melaporkannya kepada Penyidik Pegawai Negeri Sipil ITE (selanjutnya disebut dengan PPNS ITE) Direktorat Keamanan Informasi. PPNS ITE sendiri bertugas dan berfungsi menerima segala laporan tindak pidana ITE dari masyarakat. Penyampaian laporan dapat dilakukan dengan datang langsung ke ruang Subdit Penyidikan dan Penindakan Kemkominfo, melalui email ke cybercrimes@mail.kominfo.go.id, atau melalui pesan teks ke nomor Pengaduan Tindak Pidana ITE yaitu 0822-1010-1112. Dalam melangsungkan tugas dan fungsinya, PPNS ITE juga selalu berkoordinasi kepada aparat penegak hukum terkait dan Biro Korwas PPNS Bareskrim Mabes Polri. Selain menangani kasus penipuan online, PPNS ITE juga menangani kasus SARA dan fitnah di media sosial sehingga untuk menindaklanjuti laporan tersebut PPNS ITE bekerja sama dengan penyedia platform media sosial yang bersangkutan. Kemudian dalam menangani hacking pada website juga akun media social, PPNS ITE melakukan penelitian serta serangkaian proses penyidikan termasuk pemeriksaan Forensik Digital pada bukti elektronik yang diidentifikasi, dan melakukan koordinasi kepada beberapa pihak terkait untuk penanganan kasus scamming/carding. ${ }^{12}$

Perdagangan elektronik memang diatur secara umum dengan beberapa undangundang yang telah dijelaskan sebelumnya, namun belum ada pengaturan secara khusus yang mana dapat memberikan kepastian dan perlindungan hukum terutama pada jaminan perlindungan konsumen dan perlindungan data pribadi pengguna aplikasi digital. Mengingat pada pelaksanaannya banyak terjadi eksploitasi konsumen yakni minimnya pengetahuan atas hak sebagai konsumen dan prosedur penyelesaian apabila terjadi sengketa. Nilai keadilan, kemanfaatan dan kepastian hukum merupakan nilai-nilai yang mendasari berlakunya hukum. Namun dalam UU ITE asas keadilan sering kali dikesampingkan sehingga tidak adanya upaya untuk menegakkan keadilan. ${ }^{13}$

\subsubsection{Peran Badan Pengawas Perdagangan Berjangka Komoditi (Bappebti)}

Selain terdaftar di Kemkominfo, Tamasia juga diawasi oleh Bappebti, karena pada Tamasia pembelian emas dapat dilakukan dengan bayar berkala dimana nasabah dapat membayar setiap bulan sesuai dengan kemampuan dan menetapkan kapan harus melakukan pembayarannya sejak dari 3 bulan sampai 24 bulan pada saat

11 Ibid, hal. 4-5

12 Ibid, hal. 52

${ }^{13}$ Atmaja105, A. E. (2014). Kedaulatan Negara Di Ruang Maya: Kritik UU ITE Dalam Pemikiran Satipto Rahardjo. Jurnal Opinio Juris, 16(5), 48-91. 
melakukan transaksi. Undang-Undang Nomor 10 Tahun 2011 tentang Perubahan Atas Undang-Undang Nomor 32 Tahun 1997 tentang Perdagangan Berjangka Komoditi, menentukan Bappebti adalah lembaga pemerintah yang tugas pokoknya melakukan pembinaan, pengaturan, pengembangan, dan pengawasan Perdagangan Berjangka. Pembentukan dari Bappebti sendiri tentunya memiliki tujuan yaitu melindungi semua pihak yang melakukan perdagangan berjangka sehingga pelaksanaan yang teratur, wajar, efektif, dan efisien harus diwujudkan. ${ }^{14}$

Tamasia sebagai platform digital yang menyediakan jasa pembelian emas secara digital atau online ini harus memiliki emas sebelum melakukan penjualan terhadap konsumennya, kemudian harus memiliki ijin melalui Bappebti. Untuk mendapatkan ijin usaha dari Bappebti maka harus mengikuti berbagai persyaratan sebagaimana yang telah ditetapkan sesuai dengan Bidang Perdagangan Berjangka Komoditi yang tercantum pada Lampiran II Peraturan Menteri Perdagangan Republik Indonesia Nomor 77 Tahun 2018 tentang Pelayanan Menteri Berusaha Terintegrasi Secara Elektronik di Bidang Perdagangan.

Setiap transaksi jual beli emas yang dilakukan Tamasia dengan nasabahnya akan selalu diawasi oleh Bappebti, maka Bappebti juga memiliki kewenangan diantaranya: (1) meliputi menyampaikan pemahaman dan pembentukan peraturan teknis pelaksanaan perdagangan berjangka; (2) sebagai lembaga yang memberikan ijin kepada pengelola pasar dan para professional dalam perdagangan berjangka; (3) sebagai lembaga yang memberi pengesahan segala macam peraturan dan tata-tertib bursa berjangka dan lembaga kliring berjangka (termasuk persyaratan kontrak); dan (4) melangsungkan pengamatan setiap hari, pengecekan dan penyidikan terhadap aktivitas perdagangan berjangka jika menyimpang atau tidak sesuai dengan aturan hukum yang berlaku pada Undang-Undang Nomor 32 Tahun 1997 tentang Perdagangan Berjangka Komoditi. ${ }^{15}$

Sebelum nasabah melakukan transaksi jual beli emas melalui Tamasia maka harus terlebih dahulu mengunduh aplikasi Tamasia dan melakukan registrasi serta menyetujui dan menjamin Ketentuan Pengguna yang telah ditentukan Tamasia. Nasabah tidak perlu datang ke kantor pusat Tamasia guna melakukan register sebab bisa dilakukan secara online dengan mengunduh aplikasi Tamasia tersebut. Ketentuan penerimaan nasabah secara online ini sudah diatur oleh Bappebti pada Pasal 1 Peraturan Bappebti Nomor 107/BAPPEBTI/PER/11/2013.

Diatur dalam Pasal $1 \mathrm{~A}$ ayat (1) Peraturan Bappebti Nomor 107/BAPPEBTI/PER/11/2013, dijelaskan pada bidang perdagangan berjangka komoditi dalam menerima konsumen atau nasabah secara online bisa diterapkan dalam hal peruntukkan penerimaan konsumen yang memilih melakukan transaksi kontrak berjangka atau kontrak derivative dalam Sistem Perdagangan Alternatif (selanjutnya disebut SPA). Meningkatnya transaksi SPA dari tahun ketahun, menjadikan SPA menjadi bagian yang diregulasikan agar para nasabah mendapatkan perlindungan dan kepastian hukum. Bentuk perlindungan hukum terkait dengan SPA ini adalah dengan menerapkan Sistem Pengawasan Tunggal (Supervisory System) dan

14 Anggarani, S. P. (2018). Analisis Pengendalian Internal terhadap Investasi Emas (Gold) pada PT. Central Capital Future Cabang Malang. Universitas Muhammadiyah Malang, hal. 11

15 Ahmad, Heri Maros. (2016). Perlindungan Hukum terhadap Investor yang Melakukan Transaksi Jual Beli Emas Melalui Perdagangan Berjangka (Studi di PT. Rifan Financindo Berjangka Kota Medan), Universitas Muhammadiyah Sumatera Utara Medan, hal. 32 
Sistem Perdagangan dalam transaksi. Kemudian pengawasan yang dilakukan oleh Bappebti meliputi pengawasan preventif seperti arahan, pembuatan tata tertib, dan pedoman pelaksanaan, diikuti dengan pengawasan represif yang diantaranya meliputi pemeriksaan, penyidikan, dan pengenaan sanksi. ${ }^{16}$

\section{Kesimpulan}

PT Global Tamasia Sharia tidak memiliki ijin dari OJK, sebab Tamasia tidak menampung dan memutar dana nasabahnya. Tamasia merupakan platform digital dimana para nasabahnya dapat membeli dan memiliki emas dimanapun dan kapanpun. Tamasia sendiri sudah didaftarkan di PSE Kemkominfo dan diawasi oleh Bappebti. Apabila nasabah mengalami penipuan atau merasa dirugikan atas ketidaknyamanan dari pihak Tamasia, maka nasabah dapat memberikan laporan ke PPNS ITE Direktorat Keamanan Informasi atau dengan datang langsung ke ruang Subdit Penyidikan dan Penindakan Kemkominfo. Pelaporan juga dapat dilakukan melalui email ke cybercrimes@mail.kominfo.go.id. Sebelum pihak Tamasia menjual emas kepada nasabah, harus terlebih dahulu memiliki emas yang akan dijual dan mendapatkan ijin dari Bappebti. Setiap transaksi yang dilakukan oleh Tamasia dengan nasabahnya akan diawasi oleh Bappebti, adapun pengawasan tersebut terdiri dari pengawasan preventif seperti arahan, pembuatan tata tertib, dan pedoman pelaksanaan, diikuti dengan pengawasan represif yang diantaranya meliputi pemeriksaan, penyidikan, dan pengenaan sanksi.

\section{Daftar Pustaka}

\section{Buku:}

Salim, Joko. (2010). Jangan Investasi Emas sebelum Baca Buku Ini !. Jakarta: Transmedia Pustaka.

Sekretariat Ditjen Aplikasi Informatika, Kementerian Komunikasi dan Informatika. (2017). Laporan Tahunan Direktorat Jenderal Aplikasi Informatika "Peningkatan Ekonomi Kerakyatan Melalui Pemanfaatan TIK". Jakarta.

\section{Jurnal:}

Akhmaddhian, S., \& Agustiwi, A. (2018). Perlindungan Hukum Terhadap Konsumen Dalam Transaksi Jual Beli Secara Elektronik Di Indonesia. UNIFIKASI: Jurnal Ilmu Hukum, 3(2)

Atmaja105, A. E. (2014). Kedaulatan Negara Di Ruang Maya: Kritik UU ITE Dalam Pemikiran Satipto Rahardjo. Jurnal Opinio Juris, 5(16)

Brahmanta, A. G. A., \& Sarjana, I. M. (2016). Perlindungan Hukum Bagi Konsumen dalam Perjanjian Baku Jual Beli Perumahan dengan Pihak Pengembang di Bali. Acta Comitas: Jurnal Hukum Kenotariatan, (2)

Khotimah, Cindy Aulia. (2015). Perlindungan Hukum bagi Konsumen dalam Transaksi Jual Beli-Online (E-Commerce)". Bussiness Law Review, 1(14)

\footnotetext{
${ }^{16}$ Sari, M. R. P. (2013). Pengawasan Bappebti (Badan Pengawas Perdagangan Berjangka Komoditi) terhadap Pialang Perdagangan Berjangka dalam Hal Tindakan Menyalahgunakan Dana Nasabah. Kumpulan Jurnal Mahasiswa Fakultas Hukum, 1(1)
} 
Sari, M. R. P. (2013). Pengawasan Bappebti (Badan Pengawas Perdagangan Berjangka Komoditi) terhadap Pialang Perdagangan Berjangka dalam Hal Tindakan Menyalahgunakan Dana Nasabah. Kumpulan Jurnal Mahasiswa Fakultas Hukum, 1(1)

\section{Tesis atau Disertasi:}

Ahmad, Heri Maros. (2016). Perlindungan Hukum terhadap Investor yang Melakukan Transaksi Jual Beli Emas Melalui Perdagangan Berjangka (Studi di PT. Rifan Financindo Berjangka Kota Medan), Universitas Sumatera Utara Medan.

Alkaff, F. (2018). Keabsahan Transaksi Jual Beli Online (Studi Perbandingan KUH Perdata dan Kompilasi Hukum Ekonomi Syariah), Doctoral dissertation, Universitas Mataram.

Anggarani, S. P. (2018). Analisis Pengendalian Internal terhadap Investasi Emas (Gold) pada PT. Central Capital Future Cabang Malang. Universitas Muhammadiyah Malang.

Sumasyhari, Didin. (2016). Perlindungan Konsumen E-Commerce pada Lazada.co.id Tinjauan Hukum Ekonomi Islam dan Hukum Positif, Institut Agama Islam Negeri (IAIN) Surakarta.

\section{Peraturan Perundang-Undangan:}

Kitab Undang-Undang Hukum Perdata

Undang-Undang Republik Indonesia Nomor 8 Tahun 1999 tentang Perlindungan Konsumen (Lembaran Negara Republik Indonesia Tahun 1999 Nomor 42, Tambahan Lembaran Negara Republik Indonesia Nomor 3821).

Undang-Undang Republik Indonesia Nomor 11 Tahun 2008 tentang Internet dan Tranksaksi Elektronik (Lembaran Negara Republik Indonesia Tahun 2008 Nomor 58, Tambahan Lembaran Negara Republik Indonesia Nomor 4843).

Undang-Undang Republik Indonesia Nomor 39 Tahun 2008 tentang Kementerian Negara (Lembaran Negara Republik Indonesia Tahun 2008 Nomor 166, Tambahan Lembaran Negara Republik Indonesia Nomor 4916).

Undang-Undang Republik Indonesia Nomor 10 Tahun 2011 tentang Perubahan Atas Undang-Undang Nomor 32 Tahun 1997 tentang Perdagangan Berjangka Komoditi (Lembaran Negara Republik Indonesia Tahun 2011 Nomor 79, Tambahan Lembaran Negara Republik Indonesia Nomor 5232).

Undang-Undang Republik Indonesia Nomor 7 Tahun 2014 tentang Perdagangan (Lembaran Negara Republik Indonesia Tahun 2014 Nomor 45, Tambahan Lembaran Negara Republik Indonesia Nomor 5512).

Peraturan Presiden Republik Indonesia Nomor 15 Tahun 2005 tentang Perubahan Atas Peraturan Presiden Nomor 10 Tahun 2005 tentang Unit Organisasi dan Tugas Eselon I Kementerian Negara Republik Indonesia.

Peraturan Presiden Republik Indonesia Nomor 54 Tahun 2015 tentang Kementerian Komunikasi dan Informatika (Lembaran Negara Republik Indonesia Tahun 2015 Nomor 96).

Peraturan Menteri Komunikasi dan Informatika Republik Indonesia Nomor 1 Tahun 2016 tentang Organisasi dan Tata Kerja Kementerian Komunikasi dan Informatika (Berita Negara Republik Indonesia Tahun 2016 Nomor 103).

Peraturan Menteri Perdagangan Republik Indonesia Nomor 77 Tahun 2018 tentang Pelayanan Perizinan Berusaha Terintegrasi Secara Elektronik di Bidang Perdagangan, Lampiran II (Berita Negara Republik Indonesia Tahun 2018 Nomor 939). 
Peraturan Kepala Badan Pengawas Perdagangan Berjangka Komoditi Nomor 107/BAPPEBTI/PER/11/2013 tentang Perubahan Atas Peraturan Kepala Badan Pengawas Perdagangan Berjangka Komoditi Nomor 99//BAPPEBTI/PER/11/2012 tentang Penerimaan Nasabah secara Elektronik On-line di Bidang Perdagangan Berjangka Komoditi.

\section{Online/World Wide Web:}

Direktorat Tata Kelola Aplikasi Informatika. (2019). Penyelenggara Sistem Elektronik Terdaftar. Retrieved from https://pse.kominfo.go.id/pse-terdaftar, diakses 12 Juli 2019.

PT Global Tamasia Sharia. (2019). Tentang Tamasia. Retrieved from https://www.tamasia.co.id/, diakses 22 Juni 2019. 